\title{
SANKCYJNA DECYZJA NAKAZUJĄCA JAKO INSTRUMENT ZAPOBIEGANIA NEGATYWNEMU ODDZIALYWANIU NA ŚRODOWISKO
}

\begin{abstract}
Streszczenie. Celem niniejszego artykułu jest omówienie głównych problemów związanych ze stosowaniem przez organy ochrony środowiska sankcyjnej decyzji nakazującej na gruncie ustawy z 27 kwietnia 2001 r. Prawo ochrony środowiska. Od lat toczy się ożywiona dyskusja w sprawie instrumentów prawnych zapobiegania negatywnemu oddziaływaniu na środowisko. Piśmiennictwo na ten temat jest bogate. Liczba orzeczeń Naczelnego Sądu Administracyjnego świadczy o doniosłości praktycznej tego zagadnienia. Warto z tego powodu podjąć jeszcze jeden wysiłek analizy art. 363 ustawy z 27 kwietnia 2001 r. Prawo ochrony środowiska, która stanowić będzie próbę pewnej syntezy problemów związanych ze stosowaniem tej decyzji.
\end{abstract}

Słowa kluczowe: decyzja, sankcja, odpowiedzialność prawna, środowisko, oddziaływanie, ochrona środowiska.

\section{WPROWADZENIE}

Podstawowym zadaniem tego artykułu jest przedstawienie charakteru prawnego jednego z ważniejszych instrumentów odpowiedzialności administracyjnej w ochronie środowiska, jakim jest sankcyjna decyzja nakazująca uregulowana w art. 363 ustawy z 27 kwietnia 2001 r. Prawo ochrony środowiska (tekst jedn.: Dz.U. z 2019 r. poz. 1396 ze zm., dalej: p.o.ś.). Problematyka analizowana w tym artykule jest także bezpośrednio związana z wykonywaniem zadań w ochronie środowiska przez wójta, burmistrza lub prezydenta miasta jako organu ochrony środowiska (art. 376 pkt 1 p.o.ś.). Zagadnienie zadań administracji samorządowej w ochronie środowiska ma charakter złożony (Barczak 2018, 138). Cechuje je różnorodność prawnych form działania organów ochrony środowiska. Nauka prawa administracyjnego od dawna zajmuje się badaniem regulacji prawnych związanych z wykonywaniem zadań w ochronie środowiska przez organy administracji samorządowej (Barczak 2006, 34-46). Kwestie poruszone w niniejszym opracowaniu w pewnym sensie powinny uzupełnić lukę poznawczą $\mathrm{w}$ tym zakresie.

Zainteresowanie odpowiedzialnością administracyjną w ochronie środowiska jest z jednej strony konsekwencją poszerzania się obszaru obowiązków prawnych

\footnotetext{
*Uniwersytet Łódzki, Wydział Prawa i Administracji, pkorzeniowski@wpia.uni.lodz.pl.
} 
osób fizycznych niebędących podmiotami korzystającymi ze środowiska w rozumieniu art. 3 pkt 20 p.o.ś., a z drugiej zwiększeniem zakresu zadań organów ochrony środowiska. Podstawowe przyczyny i potrzeby takiej publikacji mają także uzasadnienie praktyczne związane ze stosowaniem instrumentu odpowiedzialności administracyjnej, jakim jest sankcyjna decyzja nakazująca uregulowana w art. 363 p.o.ś. Ta forma prawna działania organu ochrony środowiska stwarza dużo problemów interpretacyjnych, które zostaną zasygnalizowane w tym artykule.

Podstawową tezą badawczą tego opracowania jest wyjście od stwierdzenia, że decyzja uregulowana w art. 363 p.o.ś. jest wyrazem sankcji administracyjnej, która po spełnieniu określonych w p.o.ś. przesłanek może zostać nałożona na osobę fizyczną. Wskazuję powyższą tezę badawczą jako podstawową, biorąc pod uwagę w szczególności orzecznictwo Naczelnego Sądu Administracyjnego i poglądy wyrażone w piśmiennictwie. Uznanie powyższej tezy za prawdziwą na podstawie innych tez może bowiem odbywać się za pośrednictwem odpowiednich rozumowań (Okoń 1973, 343). Problemy stosowania sankcyjnej decyzji nakazującej stanowią przedmiot teoretyczno-doktrynalnych dociekań nauki prawa administracyjnego. Pytań, jakie mógłby postawić sobie badacz-prawnik interesujący się funkcjonowaniem instrumentów odpowiedzialności administracyjnej prawa ochrony środowiska, jest bardzo wiele. Z pytań i problemów o charakterze prawnym dwie tezy szczegółowe wydają się interesujące i doniosłe. Obejmują one określenie: 1) istoty odpowiedzialności prawnej w ochronie środowiska; 2) zakresu przedmiotowego sankcyjnej decyzji nakazującej.

Publikacja ta stawia sobie dwa cele badawcze: pierwszy - obejmuje przedstawienie charakteru prawnego sankcyjnej decyzji nakazującej w prawie ochrony środowiska; drugi - podjęcie próby na przykładzie orzecznictwa Naczelnego Sądu Administracyjnego i poglądów wyrażonych w piśmiennictwie, odpowiedzi na pytanie w jaki sposób stosowany w praktyce jest ten instrument odpowiedzialności administracyjnej w ochronie środowiska. Opracowanie niniejsze przyjmuje, że dla zachowania skuteczności sankcji administracyjnej i osiągnięcia jej celu prewencyjnego ogromne znaczenie ma systemowe wzmocnienie zasad odpowiedzialności prawnej w ochronie środowiska.

Po krótkiej charakterystyce odpowiedzialności prawnej w ochronie środowiska, dalsza część opracowania będzie poświęcona omówieniu charakteru prawnego sankcyjnej decyzji nakazującej. Badania tego zagadnienia można rozumieć jako poszukiwanie współzależności między strukturą norm dotyczących odpowiedzialności prawnej w ochronie środowiska oraz sankcji administracyjnej.

We wprowadzeniu należało również wyjaśnić znaczenie dwóch kluczowych pojęć prawnych: 1) ochrona środowiska i 2) środowisko. Zgodnie z art. 3 pkt 13 p.o.ś. przez ochronę środowiska rozumie się podjęcie lub zaniechanie działań, umożliwiające zachowanie lub przywracanie równowagi przyrodniczej; ochrona ta polega w szczególności na: a) racjonalnym kształtowaniu środowiska i gospodarowaniu zasobami środowiska zgodnie z zasadą zrównoważonego 
rozwoju, b) przeciwdziałaniu zanieczyszczeniom, c) przywracaniu elementów przyrodniczych do stanu właściwego. W myśl art. 3 pkt 39 p.o.ś. przez środowisko rozumie się ogół elementów przyrodniczych, w tym także przekształconych w wyniku działalności człowieka, a w szczególności powierzchnię ziemi, kopaliny, wody, powietrze, krajobraz, klimat oraz pozostałe elementy różnorodności biologicznej, a także wzajemne oddziaływania pomiędzy tymi elementami. Definicja ta dotyczy ogółu elementów przyrodniczych, znajdujących się zarówno w stanie naturalnym, jak też przekształconych z powodu działalności człowieka.

Definicja pojęcia „ochrona środowiska” obejmuje dwie części: 1) ogólne ustalenie zakresu działań ochronnych oraz 2) przykładowe wyliczenie tych działań (Górski 2014, 59). Ochrona środowiska obejmuje działania i zaniechania, które pozwalają na zachowania lub przywrócenie równowagi przyrodniczej niezbędnej dla realizacji zasady zrównoważonego rozwoju. Ochrona ta wyraża się w szczególności, w: 1) racjonalnym kształtowaniu środowiska i gospodarowaniu zasobami środowiska zgodnie z zasadą zrównoważonego rozwoju, 2) przeciwdziałaniu zanieczyszczeniom, 3) przywracaniu elementów przyrodniczych do stanu właściwego. Ustawodawca w p.o.ś. odszedł od wyłącznie biernej koncepcji ochrony środowiska, wskazując, że w zakresie tego pojęcia mieszczą się także aktywne formy kształtowania środowiska oraz racjonalnego gospodarowania zasobami przyrodniczymi.

Pojęcie ,środowisko" w piśmiennictwie prawniczym zmieniało się (Jastrzębski 1990, 39). Aktualana definicja ustawowa tego pojęcia uwzględnia szerokie ujęcie jego części składowych podlegających ochronie prawnej. Na podstawie tej definicji ustawowej można stwierdzić, że środowisko obejmuje całość warunków egzystencji i działalności człowieka. W ramach definicji ustawowej pojęcia środowisko ustawodawca wyodrębnił najważniejsze jego elementy przyrodnicze. Elementami przyrodniczymi są również elementy środowiska.

Waga problematyki związanej z wyjaśnieniem znaczenia dwóch ww. podstawowych pojęć prawnych ma duże znaczenie nie tylko teoretyczne, ale posiada także szczególną wartość praktyczną w procesie stosowania prawa. Każda dziedzina prawa posiada określony system podstawowych pojęć, w których wyraża, odzwierciedla istotne cechy przedmiotu prawa. Pojęcia prawne: „ochrona środowiska" i ,środowisko" tworzą twardą strukturę (rdzeń) systemu prawa ochrony środowiska. Pojęcia prawne można podzielić na teoretyczne i praktyczne. Treść pojęć teoretycznych (naukowych), takich jak np. „ochrona środowiska”, ,środowisko" została określona przez teorię, która powiązała je z praktycznymi pojęciami prawnymi takimi jak np.: ,zanieczyszczenie” czy „emisja”.

Teksty prawne składają się z pojęć teoretycznych oraz praktycznych. S. Ritterman dzieli naukowe pojęcia prawne na następujące dwie kategorie: na pojęcia zawierające cechy, które składają się na byt prawa, od których zaistnienia uzależniamy uznanie pewnego zjawiska za „prawne” i pojęcia, które dotyczą treści norm prawnych czy jej poszczególnych elementów (Ritterman 1962, 15). Dwa ww. pojęcia zawierają cechy tych dwóch kategorii teoretycznych. 


\section{POJĘCIE ODPOWIEDZIALNOŚCI PRAWNEJ}

Sankcyjna decyzja nakazująca wydawana na podstawie art. 363 p.o.ś. należy do grupy instrumentów prawnych odpowiedzialności administracyjnej w ochronie środowiska. W teorii organizacji i kierowania przyjmuje się, że „,...) odpowiedzialność zawsze może być zlokalizowana w osobie tego, kto (choć pod wpływem innych, lecz «z przekonania», a więc dowolnie) powziął decyzje" (Zieleniewski 1976, 478). Odpowiedzialność zajmuje też wysokie miejsce w hierarchii wartości-środków służących realizacji celów działania organów ochrony środowiska. O wadze i specyfice odpowiedzialności prawnej decyduje w szczególności związek określonej wartości z wieloma innymi. Odpowiedzialność prawna może być łączona z realizacją wielu wartości. Może służyć przede wszystkim przestrzeganiu prawa. W pojęciu odpowiedzialności jest wpisane poczucie zobowiązania do wzięcia na siebie skutków własnych czynów, postaw, zachowań (Tyburski 1999, 120). W ocenie K. Wojtyły, odpowiedzialność występować może tylko dlatego, że człowiek posiada zdolność odpowiadania wolą na wartości. To oznacza, że dzięki woli człowieka może odpowiadać na wartości i dokonywać czynów, za które bywa odpowiedzialny. Odpowiedzialność jest związana z wolną wolą człowieka i nie jest możliwa bez wartości. Odpowiadanie na wartości przyjmuje ostatecznie postać odpowiadania za wartości (Wojtyła 1969, 178).

Należy podkreślić, że odpowiedzialność prawna jest także ważnym elementem procesu decyzyjnego. Jest bowiem związana z zakresem czynności lub obowiązków podmiotu podejmującego decyzję lub podmiotu wykonującego decyzję. Według M. Zdyba, „Każdy kto kieruje się własną wolą podejmuje decyzje, liczyć się musi ze związaną z nimi odpowiedzialnością" (Zdyb 1990, 66).

Na gruncie teorii prawa T. Bekrycht uważa, że „Ponoszenie odpowiedzialności, czy bycie za coś odpowiedzialnym, jest swoistym ciężarem, który nosimy i którego źródła są rozmaite. W najbardziej abstrakcyjnym ujęciu źródła te stanowią trzy kategorie: psychika, prawo i moralność" (Bekrycht 2015, 5).

Problemy dotyczące zbudowania uniwersalnej definicji odpowiedzialności prawnej podnoszone są w literaturze od dawna. Wynika z nich wielość znaczeń, w jakich pojęcie to występuje w regulacjach prawnych. Według Z. Ziembińskiego, „Termin «odpowiedzialność» wskazuje, że z prawniczego punktu widzenia większy się kładzie nacisk na przypadki niezgodności rozważanego czynu z formułowanymi w normach prawnych wzorami zachowania niż na przypadki zgodności zachowania z tymi wzorami” (Ziembiński 1972, 41).

Pojęcie odpowiedzialności prawnej w naukach prawniczych jest najczęściej badane na płaszczyźnie poszczególnych gałęzi prawa: w prawie karnym, cywilnym i administracyjnym. W związku z tym jego analiza naukowa była i nadal jest przedmiotem dużego zainteresowania w piśmiennictwie związanym z głównymi dyscyplinami prawniczymi. Powiązanie zagadnienia odpowiedzialności prawnej 
z zadaniami organów ochrony środowiska wynika m. in. z tego, że stosowanie instrumentów odpowiedzialności prawnej należy do tych właśnie organów. Wykonując zadania w ochronie środowiska stosują one zróżnicowany katalog instrumentów odpowiedzialności prawnej. Odpowiedzialność prawna jest także sankcją za naruszenie prawa.

\subsection{Odpowiedzialność prawna w ochronie środowiska}

Odpowiedzialność prawna w ochronie środowiska jest aktualnym zagadnieniem badawczym systemu prawa ochrony środowiska. Istota odpowiedzialności prawnej w ochronie środowiska sprowadza się do zapewnienia wykonania nadrzędnego obowiązku ochrony środowiska i poniesienia konsekwencji prawnych jego naruszenia. Obejmują one: odpowiedzialność: administracyjną, karną (Kochanowski 1978, 28-33) i cywilną (Gruszecki 2007, 11-17). R. Paczuski wyróżnia osiem rodzajów odpowiedzialności prawnej, które mogą mieć zastosowanie do przypadków nieprzestrzegania wymagań ochrony środowiska: 1) administracyjną; 2) cywilną; 3) karną; 4) pracowniczą; 5) zawodową; 6) organizacyjną (statutową w organizacjach społecznych); 7) konstytucyjną przed Trybunałem Stanu i 8) prawnomiędzynarodową (Paczuski 2000, 136). Odpowiedzialność prawna w ochronie środowiska ma zatem charakter kompleksowy i jednocześnie złożony, i jest przedmiotem sporu (Radecki 2002, 83-84).

W sprawach ochrony środowiska odpowiedzialność prawna realizuje trzy podstawowe funkcje: 1) represyjną, 2) prewencyjną i 3) kompensacyjną. Sankcyjna decyzja nakazująca realizuje funkcje: prewencyjną i kompensacyjną ze szczególnym uwzględnieniem kryteriów celowościowo-funckcjonalnych samej sankcji administracyjnej. M. Sathl słusznie podnosi, że przepisy prawa administracyjnego co do zasady nie posługują się określeniem „sankcja administracyjna”, poprzestając na wskazywaniu konsekwencji naruszenia norm prawa administracyjnego. Brakuje też definicji legalnej sankcji administracyjnej i kompleksowej regulacji zagadnień materialno-prawnych i proceduralnych związanych ze stosowaniem sankcji. Według tej autorki, jest to pojęcie niejednoznaczne, konwencjonalne, interdyscyplinarne (Stahl 2011, 20-21).

\subsection{Odpowiedzialność administracyjna w ochronie środowiska}

Odpowiedzialność administracyjna ma coraz większe znaczenie dla osób fizycznych niebędących podmiotami korzystającymi ze środowiska, a wykonujących nałożone na nich przez organ ochrony środowiska obowiązki prawne. Jest to rodzaj odpowiedzialności prawnej, egzekwowanej przez organy ochrony środowiska, przez wydawane decyzje administracyjne. Jedną z takich decyzji jest sankcyjna decyzja nakazująca uregulowana w art. 363 p.o.ś. Podstawą odpowiedzialności administracyjnej wynikającej z tej decyzji jest czyn bezprawny, niekoniecznie zaś zawiniony (Radecki 1985, 66). Model prawny odpowiedzialności 
administracyjnej w ochronie środowiska jest także wynikiem rozszerzania się zakresu obowiązków ochronnych osób fizycznych niebędących podmiotami korzystającymi ze środowiska. A. Jaworowicz-Rudolf i M. Górski odpowiedzialność administracyjną w ochronie środowiska postrzegają jako regulowaną prawem możliwość uruchomienia wobec określonego podmiotu z powodu jego działalności naruszającej stan środowiska środków prawnych realizowanych w swoistych dla administracji formach i procedurze.

Tak sformułowane określenie odpowiedzialności administracyjnej opierają na następujących założeniach: 1) odpowiedzialność administracyjnoprawna obejmuje tylko te konsekwencje działalności naruszającej stan środowiska, które są sformułowane normatywnie, zatem ten element określenia odpowiedzialności nie ma charakteru postulatywnego; 2) odpowiedzialności podlega zawsze określony konkretnie podmiot co oznacza, że ustalenie tego podmiotu następuje w toku wypowiedzi typu aktu administracyjnego; 3) odpowiedzialność można wiązać i uruchamiać tylko z powodu naruszającej stan środowiska działalności określonego podmiotu, przez co cytowani autorzy uważają każdą działalność szkodzącą, choćby była ona dopuszczana prawnie (przez normy dopuszczalnych poziomów zanieczyszczeń czy decyzją administracyjną, zob. Jaworowicz-Rudolf, Górski 2018, 239).

Podstawowym źródłem odpowiedzialności administracyjnej jest szeroko rozumiany obowiązek prawny wynikający z ustawy. Zasadniczym celem odpowiedzialności wynikającej z art. 363 p.o.ś. jest zapobieganie negatywnemu oddziaływaniu na środowisko spowodowanemu przez osobę fizyczną. Jest to generalnie odpowiedzialność obiektywna. Po stronie osoby fizycznej niebędącej podmiotem korzystającym ze środowiska, nie wystarczy zatem wykazanie braku winy. Wymagane jest pozytywnie udowodnione podjęcie wszystkich niezbędnych środków w celu zapobieżenia powstaniu działania, które negatywnie oddziałuje na środowisko (wyr. NSA z dnia 10 kwietnia 2013 r., II GSK 2460/11, LEX nr 1337143).

\section{CHARAKTER PRAWNY SANKCYJNEJ DECYZJI NAKAZUJĄCEJ (ART. 363 P.O.Ś.)}

W piśmiennictwie wskazuje się, że decyzja uregulowana w art. 363 p.o.ś. ma charakter fakultatywny, kompetencja do jej wydania ma charakter uznaniowy (Górski 2014, 939). Według J. Starościaka, klasyfikacja aktów administracyjnych może być oparta na kryterium swobody organu administracyjnego w rozstrzyganiu spaw. Autor ten wskazuje, że „Obszerność zadań administracji, twórczy, kształtujący i przekształcający charakter jej działania, olbrzymia rozpiętość sytuacji pozornie podobnych, które ma ona rozwiązywać, uniemożliwiają prawne związanie z każdą sytuacją faktyczną gotowych skutków prawnych, czynią nieodzownym pozostawienie organowi administrującemu określonego stopnia 
samodzielności działania" (Starościak 1975, 237-238). Uznanie administracyjne nie może oznaczać dowolności działania organu ochrony środowiska w rozstrzygnięciu sprawy. Organ ten nie jest bowiem zwolniony w szczególności z obowiązku przeprowadzenia pełnych i precyzyjnych ustaleń co do stanu faktycznego i oceny, czy okoliczności sprawy odpowiadają przesłankom do wydania sankcyjnej decyzji nakazującej. M. Jaśkowska uważa, że „Dzisiejszy sposób rozumienia uznania wiąże się, jak już wielokrotnie podkreślano z koncepcją administracji jako działalności skrępowanej przepisami prawa" (Jaśkowska 2010, 247).

Z powyższego wynika, że sankcyjna decyzja nakazująca ma złożony charakter prawny, czego wyrazem jest jej zakres podmiotowy i przedmiotowy.

\subsection{Zakres podmiotowy sankcyjnej decyzji nakazującej}

Dopiero stwierdzenie przez organ ochrony środowiska wystąpienia działania osoby fizycznej, która negatywnie oddziałuje na środowisko pozwoli temu organowi na zastosowanie tzw. uznania administracyjnego. Oznacza to, że organ ochrony środowiska może, ale nie musi, nałożyć na osobę fizyczną obowiązki sprowadzające się do: 1) ograniczenia negatywnego oddziaływania na środowisko i jego zagrożenia; 2) przywrócenia środowiska do stanu właściwego. Według NSA,

Oparcie decyzji na konstrukcji swobodnego aktu administracyjnego tzw. uznania administracyjnego, oznacza, że organ administracji nie jest obowiązany do wydania jednoznacznej w treści decyzji w razie spełnienia czy zaistnienia ściśle określonych warunków (...). Podjęcie rozstrzygnięcia w oparciu o uznanie administracyjne (dyspozycja przepisu stanowiącego podstawę aktu swobodnego uznania skonstruowana jest m.in. przy użyciu wyrażenia „organ może") stanowi skorzystanie z uprawnienia administracji do ukształtowania w danej sprawie i w danym stanie faktycznym skutków prawnych w ramach pewnej swobody zakreślonej przepisem prawa materialnego oraz $\mathrm{w}$ ramach obowiązujących reguł procesowych. Innymi słowy, działając w ramach swobodnego uznania, organ administracji ma możliwość wyboru rozstrzygnięcia w określonym stanie faktycznym. Powyższe nie oznacza, że możliwość wykorzystania przez organ luzu decyzyjnego pozwala na podjęcie decyzji w sposób dowolny tzn. wedle schematu: jeżeli można rozstrzygnąć na korzyść strony, lecz nie ma takiego obowiązku, to żądania nie uwzględnia się przy jednoczesnym braku wyczerpującego wyjaśnienia wszystkich przesłanek takiego działania (wyr. NSA z dnia 25 lutego 2015 r. II GSK 193/14, LEX nr 1658374).

Kontrola sądu administracyjnego będzie w takiej sprawie polegać na zbadaniu, czy organ ochrony środowiska nie przekroczył granic uznania administracyjnego (Stelmasiak 2003, 312-316).

Adresatem sankcyjnej decyzji nakazującej jest osoba fizyczna niebędąca podmiotem korzystającym ze środowiska, której działanie negatywnie oddziałuje na środowisko (art. 363 ust. 1 p.o.ś.). Zdaniem M. Górskiego, „Decyzja Wójta może pojawić w sytuacji, w której działalność osoby fizycznej powoduje negatywne skutki w środowisku (negatywnie oddziałuje na środowisko). Pojęcie «negatywne skutki» czy «negatywne oddziaływanie» to pojęcia niedookreślone, 
występujące jednak w ustawie dość często (...)" (Górski 2008, 72). Według NSA, podstawą zastosowania tego przepisu musi być ustalenie osoby fizycznej, której działanie negatywnie oddziałuje na środowisko (wyr. NSA z dnia 17 listopada 2017 r., II OSK 1484/16, LEX nr 2418596).

Kryterium wyboru adresata decyzji nakładającej obowiązki z art. 363 ust. 1 p.o.ś. powinno być zastosowane $\mathrm{z}$ uwzględnieniem wystąpienia przesłanki w postaci negatywnego oddziaływania osoby fizycznej na środowisko. Celem sekcyjnej decyzji nakazującej jest doprowadzenie do: 1) ograniczenia negatywnego oddziaływania na środowisko i jego zagrożenia; 2) przywrócenia środowiska do stanu właściwego.

Dokonując ustalenia osoby fizycznej, na którą mogą być nałożone obowiązki uregulowane w art. 363 ust. 1 p.o.ś., organ ochrony środowiska powinien mieć na względzie, że nie jest dopuszczalne przeniesienie na inną osobę fizyczną uprawnień lub obowiązków wynikających z przepisów prawa administracyjnego na mocy czynności cywilnoprawnej. B. Rakoczy uważa, że „Adresatem decyzji może być tylko osoba fizyczna, której działalność negatywnie oddziałuje na środowisko. Lege non distinguente chodzi o każdy rodzaj działalności, nie tylko o działalność gospodarczą" (Rakoczy 2013, 657). Należy zgodzić się z tym poglądem.

Trudności związane z ustaleniem właściwego podmiotu, który powinien być adresatem decyzji wydanej na podstawie art. 363 p.o.ś., nie mogą spowodować sytuacji, w której adresatem nakazów wynikających z art. 363 ust. 1 p.o.ś. będzie np. gmina. Jednostka samorządu terytorialnego nie może przejmować obowiązków prawnych skierowanych do osób fizycznych. Zakres, w jakim zostaną nałożone na osobę fizyczną nakazy wynikające $\mathrm{z}$ art. 363 ust. 1 p.o.ś. zależy od tego, jaki jest zakres i rodzaj negatywnego oddziaływania na środowisko i jego skutki. W postępowaniu w przedmiocie wydania sankcyjnej decyzji nakazującej na podstawie art. 363 p.o.ś. organ ochrony środowiska powinien prawidłowo ustalić stan faktyczny sprawy, w szczególności właściwie określić osobę fizyczną, której działanie negatywnie oddziałuje na środowisko. Postępowanie administracyjne toczące się w takiej sprawie powinno przede wszystkim wykazać w sposób niebudzący wątpliwości, że stroną postępowania jest wskazana w decyzji osoba fizyczna, której działanie negatywnie oddziałuje na środowisko.

\subsection{Zakres przedmiotowy sankcyjnej decyzji nakazującej}

Zakres przedmiotowy analizowanej decyzji obejmuje nakazy określonego zachowania się przez osobę fizyczną. W prakseologii nakaz oznacza dyrektywę praktyczną podającą, co koniecznie trzeba zrobić, jeżeli się chce osiągnąć zdarzenie zamierzone jako cel. Podstawą teoretyczną nakazu praktycznego jest twierdzenie, które podaje warunki konieczne lub dostateczne do wywołania danego zdarzenia (Pszczołowski 1978, 127). 
Decyzja nakazująca: 1) ograniczenie negatywnego oddziaływania na środowisko i jego zagrożenia; 2 ) przywrócenie środowiska do stanu właściwego nakłada na osobę fizyczną obowiązek administracyjny. Adresat takiej decyzji jest obowiązany do wykonania nałożonych na niego obowiązków prawnych. Przez wykonanie decyzji wydanej na podstawie art. 363 p.o.ś. należy rozumieć wszelkie działania osoby fizycznej zmierzające do uzyskania stanu wynikającego z danej decyzji, w tym przede wszystkim realizacji wynikających z niej obowiązków prawnych, których celem jest 1) ograniczenie negatywnego oddziaływania na środowisko i jego zagrożenia; 2) przywrócenie środowiska do stanu właściwego. Są to zatem wszelkie zachowania osoby fizycznej (działania i zaniechania) zmierzające do uzyskania stanu wynikającego z nałożonych na nią obowiązków.

Zasadniczą przesłanką wydania sankcyjnej decyzji nakazującej jest takie działanie osoby fizycznej, która negatywnie oddziałuje na środowisko. Sankcyjna decyzja nakazująca może być wydana, o ile zostanie jednoznacznie stwierdzone, że działanie osoby fizycznej negatywnie oddziałuje na środowisko. Określenie „której działanie negatywnie oddziałuje na środowisko” nie jest uregulowane w p.o.ś. W piśmiennictwie przyjmuje się, że chodzi „o jakąkolwiek zmianę środowiska czy jego elementu na niekorzyść, ale w porównaniu ze stanem przed podjęciem danego działania, a nie w odniesieniu do hipotetycznego stanu idealnego czy określonego np. standardami jakości (Górski 2014, 935). Należy zatem zawsze ustalić stan wyjściowy środowiska, który następnie uległ pogorszeniu z powodu negatywnego oddziaływania na środowisko. Według NSA, ,(...) art. 363 ust. 1 p.o.ś. będzie miał zastosowanie w każdym przypadku wystąpienia negatywnego oddziaływania na środowisko. Przesłanką wydania decyzji na podstawie art. 363 ust. 1 p.o.ś., jest naruszenie obowiązku polegającego na zakazie powodowania negatywnego oddziaływania na środowisko. Zakaz ten jest formą prawną szeroko rozumianego celu normatywnego w postaci obowiązku ochrony środowiska. Tworzy on obiektywne i subiektywne warunki, niezbędne dla niezakłóconego korzystania ze środowiska w ramach powszechnego korzystania ze środowiska. Potrzeba zapewnienia racjonalnych warunków korzystania ze środowiska określa zakres przedmiotowy decyzji wydawanej na podstawie art. 363 ust. 1 p.o.ś. Wydanie decyzji, o której mowa w art. 363 ust. 1 p.o.ś., jest dopuszczalne w sytuacji, gdy jej adresat narusza obowiązek polegający na zakazie powodowania negatywnego oddziaływania na środowisko" (wyr. NSA z dnia 21 listopada 207 r., II OSK 516/16, LEX nr 2428638). W orzecznictwie NSA wyrażono pogląd, według którego „(...) przy podejmowaniu interwencji wynikających z uciążliwości związanej z oddziaływaniem niewłaściwego składowania obornika oraz sianokiszonki w gospodarstwie rolnym, gmina może wykorzystywać uprawnienia kontrolne wynikające z art. 379 p.o.ś. oraz art. 363 tej ustawy. Wójt, burmistrz lub prezydent miasta może w drodze decyzji nakazać osobie fizycznej, której działalność negatywnie oddziałuje na środowisko, wykonanie w określonym czasie czynności zmierzających do ograniczenia negatywnego oddziaływania na środowisko. Uciążliwości 
związane ze składowaniem np. obornika oraz sianokiszonki w nieodpowiednim miejscu niewątpliwie mogą stanowić uciążliwości dla środowiska, co w konsekwencji wskazuje na kompetencję organu gminy" (postanowienie NSA z dnia 5 marca 2019 r., II OW 230/18, LEX 2642380).

Źródło kompetencji wynikających z art. 363 p.o.ś. jest niezależnie od uprawnień organów Inspekcji Ochrony Środowiska (postanowienia NSA z dnia 26 października 2017 r., II OW 80/17 oraz postanowienie NSA z dnia 15 grudnia 2017 r., II OW 111/17 dostępne na stronie: http://orzeczenia.nsa.gov.pl).

Negatywne oddziaływanie na środowisko może naruszać zarówno interes społeczny, jak również interes indywidualny strony. Zdaniem W. Katnera, „Nieskażone środowisko naturalne stanowi pewną wartość obiektywną, wspólną wszystkim ludziom, a jednocześnie bezpośrednio dotyczącą każdego człowieka. Dlatego też szkodliwe oddziaływanie na środowisko powoduje - z jednej strony - zachwianie równowagi w przyrodzie, a $\mathrm{z}$ drugiej - łączące się z tym naruszenie podstawowych elementów, warunkujących życie konkretnych osób" (Katner 1982, 187).

W uzasadnieniu rozstrzygnięcia organu ochrony środowiska wydanego na podstawie art. 363 ust. 1 p.o.ś. powinno się znaleźć wskazanie na jakich przesłankach organ ochrony środowiska oparł się wydając analizowaną decyzję. W sprawach, których dotyczy treść art. 363 ust. 1 organ ochrony środowiska powinien uwzględnić nie tylko interes społeczny w postaci ochrony środowiska, ale również słuszny interes strony. Według J. Stelmasiaka, „organ administracyjny, przed którym toczy się dane postępowanie administracyjne, jest władny określić, co należy uznać za słuszne z punktu widzenia interesu publicznego (społecznego), biorąc pod uwagę, że naruszenie wymagań ochrony środowiska nie uznaje granic podziałów terytorialnych" (Stelmasiak 2013, 17-18).

W sankcyjnej decyzji nakazującej, organ ochrony środowiska na postawie art. 363 ust. 1 p.o.ś., może nakazać wykonanie w określonym czasie czynności zmierzających do: 1) ograniczenia negatywnego oddziaływania na środowisko i jego zagrożenia; 2) przywrócenia środowiska do stanu właściwego. Analizując ogólny charakter prawny obowiązków wynikających z treści analizowanej decyzji, można wskazać na następujące zależności: 1) zachodzi tu brak możności wyboru określonego postępowania ze strony adresata nakazu, przeciwnie, istnieje obowiązek określonego postępowania wynikającego z decyzji; 2) nakaz nałożony decyzją wynika z prawa $\mathrm{w}$ znaczeniu przedmiotowym, inaczej mówiąc, nie ma nakazu bez normy; 3) w przypadku sporu, konieczność wskazania podstawy prawnej, z której wynika nakaz określonego postępowania osoby fizycznej niebędącej podmiotem korzystającym ze środowiska, ciąży na organie ochrony środowiska żądającym wykonania tego nakazu przez osobę fizyczną (Siemieński 1976, 124-125). Zdaniem M. Górskiego,

Traktując nakaz i zakaz jako instytucje administracyjnego prawa materialnego, a więc obowiązki o charakterze administracyjnoprawnym, należałoby oczywiście przyjąć, że chodzi 
tu o obowiązki wynikające z norm prawa administracyjnego, a więc takie, które są podstawą powstania stosunku administracyjnoprawnego. Tego rodzaju stosunek prawny może powstać bezpośrednio w związku z kształtowaniem treści nakazu czy zakazu przez właściwy do tego organ administracji, jego powstanie może jednak być także związane z wykonywaniem przez organ administracji funkcji nadzorczych wobec podmiotów, do których kierowany jest nakaz bądź zakaz, wynikający wprost z przepisu powszechnie obowiązującego (Górski 2017, 232).

Zakaz powodowania negatywnego oddziaływania na środowisko jest konsekwencją obowiązku ochrony środowiska. W myśl 86 Konstytucji RP każdy jest obowiązany do dbałości o stan środowiska i ponosi odpowiedzialność za spowodowane przez siebie jego pogorszenie. Zasady tej odpowiedzialności określa ustawa. Potrzeba zapewnienia racjonalnych warunków korzystania ze środowiska określa zakres przedmiotowy sankcyjnej decyzji nakazującej. Jest on ukształtowany przede wszystkim przez podstawowe funkcje prawa ochrony środowiska. Wydanie sankcyjnej decyzji nakazującej jest dopuszczalne w sytuacji, gdy jej adresat narusza w sposób bezpośredni obowiązek polegający na zakazie powodowania negatywnego oddziaływania na środowisko. Obowiązek w tym przypadku oznacza konieczność podjęcia pewnych czynności, co wynika z zakazu określonego w art. 363 ust. 1 p.o.ś. Obowiązek prawny może oznaczać powinność lub zobowiązanie. W piśmiennictwie przyjmuje się, że obowiązek, zakaz i dozwolenie mogą być relatywizowane do pewnego zbioru nakazów np. chroniących środowisko. Pojęcia deontyczne mogą mieć zastosowanie w przypadkach, w których obowiązek, zakaz i dozwolenie nie zależą od obowiązywania określonych norm (Ziemba 1983, 115).

Obowiązek należy do podstawowych pojęć prawnych i prawniczych. Obowiązek prawny polegający na zakazie powodowania negatywnego oddziaływania na środowisko może sprowadzać się zatem do tego, że przepis prawa ustanawia dla osoby fizycznej niebędącej podmiotem korzystającym ze środowiska nakaz określonego zachowania się (działania lub zaniechania). Niezastosowanie się do zakazu negatywnego oddziaływania na środowiska może być wydanie w drodze decyzji nakazu, którego przedmiotem może być wykonanie w określonym czasie czynności zmierzających do: 1) ograniczenia negatywnego oddziaływania na środowisko i jego zagrożenia; 2) przywrócenia środowiska do stanu właściwego. Powodowanie negatywnego oddziaływania na środowisko wytwarza stan niewypełnienia obowiązku wynikającego z art. 363 ust. 1 p.o.ś. Zachowanie będące przedmiotem tak sformułowanego obowiązku prawnego wynikające $\mathrm{z}$ ww. przepisu może być zatem nakazane lub zakazane. Oznacza to, że po stronie osoby fizycznej niebędącej podmiotem korzystającym ze środowiska może wystąpić obowiązek pozytywny lub negatywny związany z zakazem negatywnego oddziaływania na środowisko. W art. 363 ust. 1 pkt 1 p.o.ś. ustawodawca uregulował nakaz ograniczania zagrożenia dla środowiska. W piśmiennictwie wskazuje się, że „Katalog współczesnych problemów związanych z zagrożeniem człowieka i jego najbliższego środowiska stanowią: metale ciężkie (ołów, rtęć, kadm) i inne 
związki chemiczne (np. fluor), które przenikają do środowiska i zagrażają żywym organizmom; środki ochrony roślin (herbicydy); substancje nawozowe; lekarstwa i związki o specjalnym działaniu; substancje pomocnicze i dodatki do środków spożywczych (substancje barwiące i konserwujące, emulgujące i stabilizujące, antyutleniacze i inne)" (Głowiak 1985, 46).

Organ ochrony środowiska nakładając w decyzji na osobę fizyczną nakaz ograniczenia oddziaływania na środowisko i jego zagrożenia powinien uwzględnić treść zasad ogólnych prawa ochrony środowiska, a w szczególności: prewencji i przezorności (art. 6 ust. 1 i 2 p.o.ś.). Podstawowym celem sankcyjnej decyzji nakazującej jest zapobieganie negatywnemu oddziaływaniu na środowisko przez osobę fizyczną. Decyzja ta realizuje funkcję prewencyjną prawa ochrony środowiska. Wydając sankcyjną decyzję nakazującą organ ochrony środowiska powinien dążyć do zapobiegania negatywnemu oddziaływaniu na środowisko przez osobę fizyczną. Wydanie takiej decyzji może mieć miejsce, kiedy negatywne oddziaływanie na środowisko istnieje $\mathrm{w}$ stanie początkowym. Organ ochrony środowiska, kierując się zasadami prewencji i przezorności, nakładając na osobę fizyczną nakazy uregulowane w art. 363 ust. 1 pkt 1 i 2 p.o.ś., powinien ocenić skalę działania negatywnie oddziałującego na środowisko. Według M. Górskiego, art. 363 ust. 1 p.o.ś. wydaję się być niekonsekwentny dopuszczając sytuację, w której mimo wydania decyzji i jej wykonania negatywne oddziaływania - mimo że o mniejszym zakresie - pozostaną. Decyzja ta ma bowiem zmierzać do ograniczenia, a nie wyłączenia (zlikwidowania) takiego negatywnego oddziaływania (Górski 2014, 940). A. Podniesiński analizując problem ważniejszych rodzajów zagrożeń środowiska i ich ograniczania, zwraca uwagę na cztery główne zagrożenia środowiska: odpady, hałas i wibracja, promieniowanie (Podniesiński 1979, 147).

$\mathrm{Z}$ treści art. 363 ust. 1 p.o.ś. wynika zarówno zobowiązanie do ograniczenia negatywnego oddziaływania na środowisko, jak i zobowiązanie do przywrócenia środowiska do stanu właściwego. Obowiązki te mogą być nałożone w decyzji łącznie bądź oddzielnie na podstawie wykazanego w toku postępowania administracyjnego negatywnego oddziaływania na środowisko. Decyzja wydawana na podstawie art. 363 ust. 1 ma wyraźnie sankcyjny charakter. Jej wydanie może mieć miejsce jedynie w sytuacji, w której jej potencjalny adresat narusza obowiązek polegający na zakazie powodowania negatywnego oddziaływania na środowisko. Słowo „oddziaływanie” w odniesieniu do osoby fizycznej niebędącej podmiotem korzystającym ze środowiska, oznacza wywoływanie zmiany lub utrzymywanie stanu rzeczy, czyli od strony analizowanego tu obowiązku prawnego - niedopuszczenie do zmiany. Uwzględniając pozycję tego oddziaływania w łańcuchu zdarzeń w odniesieniu do danego skutku dla środowiska, można rozróżnić oddziaływanie pośrednie i bezpośrednie. „Oddziaływanie” jest terminem, którego znaczenie jest szersze od pojęcia „działanie”, które można traktować jako pewien rodzaj wpływu na coś lub kogoś (w tym przypadku na środowisko). Termin działanie dotyczy człowieka, natomiast na człowieka lub środowisko może oddziaływać jakaś rzecz 
albo kompleks rzeczy (Pszczołowski 1978, 143). Takim kompleksem rzeczy może być np. emisja lub zanieczyszczenie.

Zgodnie $\mathrm{z}$ art. 363 ust. 2 p.o.ś. 2. przepisy art. 362 ust. 2-5 p.o.ś. stosuje się odpowiednio. Zwrot legislacyjny użyty w art. 363 ust. 2 p.o.ś. „stosuje się odpowiednio" oznacza, że wskazane przez art. 363 ust. 2 przepisy mają zastosowanie lecz z niezbędnymi modyfikacjami, podyktowanymi specyfiką postępowania w sprawie wydania sankcyjnych decyzji oraz odpowiedzialności administracyjnej w ochronie środowiska. Odpowiednie stosowanie przepisów polega na tym, że niektóre $\mathrm{z}$ nich stosowane są wprost, inne ulegają modyfikacji, a jeszcze inne w ogóle nie mogą być stosowane. Ocena zakresu odpowiedniego stosowania przepisu musi także uwzględniać cel regulacji.

\section{ZAKOŃCZENIE}

Stosowanie władczych form działania organów ochrony środowiska, do jakich zalicza się sankcyjna decyzja nakazująca, należy do kluczowych zagadnień administracyjnoprawnych w procesie wykonywania zadań administracji publicznej, będących przedmiotem zainteresowań doktryny, legislacji i orzecznictwa. Władcze formy działania administracji w ochronie środowiska ulegają wielostronnym i zasadniczym przeobrażeniom. Sedno prewencyjnej ochrony prawnej środowiska jest związane ze stosowaniem nakazów administracyjnoprawnych. W ochronie środowiska zmieniają się formy i metody działania organów ochrony środowiska. Nowe wyzwania związane $\mathrm{z}$ ochroną środowiska powinny stanowić impuls dla ciągłego doskonalenia modelu prawnego form działania organów ochrony środowiska. Jest to szczególne wyzwanie dla prawodawcy.

Przechodząc w podsumowaniu do oceny charakteru prawnego sankcyjnej decyzji nakazującej należy stwierdzić, że określa go wyraźnie art. 363 p.o.ś. Jest to decyzja sankcyjna. Stwarza ona dla osoby fizycznej, której działanie negatywnie oddziałuje na środowisko, sytuację przymusową. Decyzja wydana na podstawie art. 363 ust. 1 p.o.ś. nie stwierdza stanu już istniejącego, ale reguluje nowy stan, w którym doszło do negatywnego oddziaływania na środowisko. Decyzja ta tworzy dla osoby fizycznej nowy obowiązek i nowy stan prawny na przyszłość (ex nunc). Tego rodzaju decyzje nazywane są też decyzjami ustalającymi. Jest zatem decyzją konstytutywną. Nie można też zapominać, że decyzja ta poza funkcją prewencyjną, pełni również funkcję restytucyjną i represyjną. W ramach funkcji resytytucyjnej decyzja ta ma wyrównać stratę w środowisku, jaką spowodowała osoba fizyczna przez negatywne oddziaływanie na środowisko. Funkcja represyjna tej decyzji sprowadza się do stworzenia dla osoby fizycznej niedogodności polegającej na wykonaniu w określonym czasie czynności, będących wynikiem negatywnego oddziaływania na środowisko. Art. 363 p.o.ś. stanowi normę 
kompetencyjną, wyrażającą obowiązek organu ochrony środowiska do wydania decyzji przy spełnieniu określonych w tym przepisie przesłanek.

$\mathrm{Z}$ treści art. 363 p.o.ś. dla osoby fizycznej, której działanie negatywnie oddziałuje na środowisko, wynika norma postępowania w sposób określony w decyzji administracyjnej. Art. 363 p.o.ś. zawiera normę sankcjonowaną. W odpowiedzialności administracyjnej w ochronie środowiska normy tego rodzaju spełniają rolę podstawową. Istotą tej decyzji administracyjnej jest skierowany do osoby fizycznej nakaz wykonania w określonym czasie czynności zmierzających do: 1) ograniczenia negatywnego oddziaływania na środowisko i jego zagrożenia; 2) przywrócenia środowiska do stanu właściwego. Przepis art. 363 p.o.ś. w sposób zamknięty wylicza rodzaje czynności, które mogą być objęte nakazem wynikającym z wydania przedmiotowej decyzji. Mogą one występować samodzielnie lub w powiązaniu ze sobą. Decyzja ta ma charakter fakultatywny, kompetencja do jej wydania przez organ ochrony środowiska ma charakter uznaniowy. Charakter uznaniowy tej decyzji nie może oznaczać dowolności działania organu ochrony środowiska w rozstrzygnięciu sprawy na podstawie art. 363 p.o.ś. Organ ten nie jest zwolniony w szczególności z obowiązku przeprowadzenia pełnych i precyzyjnych ustaleń co do stanu faktycznego i oceny, czy okoliczności sprawy odpowiadają przesłankom do wydania sankcyjnej decyzji nakazującej.

\section{BIBLIOGRAFIA}

Barczak, Anna. 2006. Zadania samorzadu terytorialnego w zakresie ochrony środowiska. Warszawa: $\mathrm{ABC}$.

Barczak, Anna. 2018. „Reglamentacja gospodarki odpadami”. W Reglamentacja korzystania ze środowiska jako funkcja administracji samorzadowej. 138-147. Red. Piotr Korzeniowski, Iwona M. Wieczorek. Łódź: Instytut Samorządu Terytorialnego.

Bekrycht, Tomasz. 2015 „Wprowadzenie”. W O pojęciu odpowiedzialności z perspektywy zagadnień filozoficznoprawnych $i$ wybranych dogmatyk prawniczych. 5-8. Red. Tomasz Bekrycht. Łódź: Wydawnictwo Uniwersytetu Łódzkiego.

Bukowski, Zbigniew. Ewa Katarzyna Czech. Karolina Karpus. Bartosz Rakoczy. 2013. Prawo ochrony środowiska. Komentarz. Warszawa: Wolters Kluwer Polska.

Górski, Marek. 2008 Odpowiedzialność administracyjnoprawna $w$ ochronie środowiska. Odpowiedzialność za szkody $w$ środowisku inne instrumenty odpowiedzialności administracyjnoprawnej. Warszawa: Oficyna Wolters Kluwer Business.

Górski, Marek. 2014. Prawo ochrony środowiska. Komentarz. Warszawa: Wydawnictwo C.H. Beck.

Górski, Marek. 2017. „Nakaz i zakaz”. W Prawo administracyjne materialne. System prawa administracyjnego. Tom 7. 232-244. Red. Roman Hauser, Zygmunt Niewiadomski, Andrzej Wróbel. Warszawa: Wydawnictwo C.H. Beck. Instytut Nauk Prawnych PAN.

Gruszecki, Krzysztof. 2007. „Zbieg odpowiedzialności administracyjnej z odpowiedzialnością karną lub cywilną z tytułu szkodliwego korzystania ze środowiska. Glosa do wyroku NSA z 21 lutego 2006 r., II OSK 339/05”. Gdańskie Studia Prawnicze. Przegląd Orzecznictwa 3: $11-17$.

Jastrzębski, Ludwik. 1990. Prawo ochrony środowiska w Polsce. Warszawa: Państwowe Wydawnictwo Naukowe. 
Jaśkowska, Małgorzata. 2010. „Uznanie administracyjne a inne formy władzy dyskrecjonalnej administracji publicznej”. W Instytucje prawa administracyjnego. System prawa administracyjnego. Tom 1. 213-303. Red. Roman Hauser, Zygmunt Niewiadomski, Andrzej Wróbel. Warszawa: Wydawnictwo C.H. Beck. Instytut Nauk Prawnych PAN.

Jaworowicz-Rudolf, Agnieszka. Marek Górski. 2018. „Odpowiedzialność administracyjna”. W Prawo ochrony środowiska. Red. Marek Górski. Warszawa: Wydawnictwo Wolters Kluwer.

Katner, Wojciech. 1982. Ochrona własności nieruchomości przed naruszeniami pośrednimi. Warszawa: Wydawnictwo Prawnicze.

Kempa, Edward. 1985. „Czystość środowiska”. W Podstawy ochrony środowiska. Red. Bohdan Głowiak, Edward Kempa, Tomasz Winnicki. Warszawa: Państwowe Wydawnictwo Naukowe.

Kochanowski, Janusz. 1978. „O przekształceniu się odpowiedzialności karnej”. Państwo i Prawo 6: $17-22$.

Okoń, Wincenty. 1973. Elementy dydaktyki szkoły wyższej. Warszawa: Państwowe Wydawnictwo Naukowe.

Paczuski, Ryszard. 2000. Prawo ochrony środowiska. Bydgoszcz: Oficyna Wydawnicza Branta.

Podniesiński, Antoni. 1979. Podstawowe problemy ochrony środowiska w Polsce. Warszawa: Państwowe Wydawnictwo Rolnicze i Leśne.

Pszczołowski, Tadeusz. 1978. Mała encyklopedia prakseologii i teorii organizacji. WrocławWarszawa-Kraków-Gdańsk: Zakład Narodowy imienia Ossolińskich.

Radecki, Wojciech. 1985. Odpowiedzialność administracyjna $w$ ochronie środowiska. WrocławWarszawa-Kraków-Gdańsk-Łódź: Zakład Narodowy imienia Ossolińskich.

Radecki, Wojciech. 2002. Odpowiedzialność prawna w ochronie środowiska. Warszawa: Difin.

Ritterman, Stefan. 1962. Pojęcia materialne $w$ prawie cywilnym. Studium z zakresu metodologii nauki prawa cywilnego. Rozważania ogólne. Kraków: Państwowe Wydawnictwo Naukowe.

Siemieński, Feliks. 1976. Prawo konstytucyjne. Warszawa-Poznań: Państwo Wydawnictwo Naukowe.

Stahl, Małgorzata. 2011. „Wprowadzenie. Sankcje administracyjne - problemy węzłowe”. W Sankcje administracyjne. Blaski i cienie. Red. Małgorzata Stahl, Renata Lewicka, Marek Lewicki. Warszawa: Wolters Kluwer Polska.

Starościak, Jerzy. 1975. Prawo administracyjne. Warszawa: Państwowe Wydawnictwo Naukowe.

Stelmasiak, Jerzy. 2003. „Wybrane zagadnienia dotyczące źródeł prawa administracyjnego w świetle orzecznictwa Naczelnego Sądu Administracyjnego". W Polski model sadownictwa administracyjnego. Red. Jerzy Stelmasiak, Janusz Niczyporuk, Sławomir Fundowicz. Lublin: Oficyna Wydawnicza VERBA.

Stelmasiak, Jerzy. 2013. Interes indywidualny a interes publiczny $w$ ochronie środowiska w obszarze specjalnym o charakterze ekologicznym. Rzeszów: Wydawnictwo Uniwersytetu Rzeszowskiego.

Tyburski, Włodzimierz. 1999. „Główne kierunki i zasady etyki środowiskowej”. W Wprowadzenie do filozoficznych problemów ekologii. 97-132. Red. Andrzej Papuziński. Bydgoszcz: Wydawnictwo Uczelniane Wyższej Szkoły Pedagogicznej w Bydgoszczy.

Wojtyła, Karol. 1969. Osoba i czyn. Kraków: Polskie Towarzystwo Teologiczne.

Zdyb, Marian. 1990. Istota decyzji. Personalistyczna - normatywistyczna analiza zjawiska. Lublin: Wydawnictwo Uniwersytetu Marii Curie-Skłodowskiej.

Zieleniewski, Jan. 1976. Organizacja zespołów ludzkich. Wstęp do teorii organizacji i kierowania. Warszawa: Państwowe Wydawnictwo Naukowe.

Ziemba, Zdzisław. 1983. Analityczna teoria obowiazku. Studium z logiki deontycznej. Warszawa: Państwowe Wydawnictwo Naukowe.

Ziembiński, Zygmunt. 1972. Analiza pojęcia czynu. Warszawa: Wiedza Powszechna. 


\title{
Akty prawne
}

Ustawa z 27 kwietnia 2001 r. Prawo ochrony środowiska (tekst jedn.: Dz.U. z 2019 r., poz. 1396 ze zm.).

\section{Orzecznictwo}

Postanowienia NSA z 26 października 2017 r., II OW 80/17, http:/orzeczenia.nsa.gov.pl [dostęp: 21.03.2020].

Postanowienie NSA z 15 grudnia 2017 r., II OW 111/17, http:/orzeczenia.nsa.gov.pl [dostęp: 21.03.2020].

Postanowienie NSA z 5 marca 2019 r., II OW 230/18, LEX 2642380 [dostęp: 21.03.2020].

Wyrok NSA z 10 kwietnia 2013 r., II GSK 2460/11, LEX nr 1337143 [dostęp: 21.03.2020].

Wyrok NSA z 25 lutego 2015 r., II GSK 193/14, LEX nr 1658374 [dostęp: 21.03.2020].

Wyrok NSA z 17 listopada 2017 r., II OSK 1484/16, LEX nr 2418596 [dostęp: 21.03.2020].

Wyrok NSA z 21 listopada 2017 r., II OSK 516/16, LEX nr 2428638 [dostęp: 21.03.2020].

\section{Piotr Korzeniowski}

\section{PENALTY PRESCRIPTIVE DECISION AS A TOOL TO PREVENT ADVERSE INFLUENCE ON THE ENVIRONMENT}

\begin{abstract}
The aim of this paper is to discuss the main issues related to penalty prescriptive decisions, used by environmental protection authorities pursuant to the Act of $27^{\text {th }}$ April 2001 on the environmental protection. The question of the legal instruments to prevent adverse influence on the environment has been discussed since many years. There are many publications in the literature devoted to this problem. As it can be seen from the number of the judgements issued by the Supreme Administrative Court, the practical side of the problem is of significance. For this reason, it is worth to make once again an attempt to analyse Art. 363 of the Act of $27^{\text {th }}$ April 2001 on the environmental protection, which would constitute an attempt to make a certain synthesis of the problems arising from the application of such decisions.

Keywords: decision, penalty, legal responsibility, environment, influence, environmental protection.
\end{abstract}

